\title{
Effect of exercise training on gene expression of adiponectin and its receptors in testicles and sex hormones in diabetic rats
}

\author{
Zahra Nadi, ${ }^{1}$ Mohammad Bayat, ${ }^{1}$ Hadi Karami, ${ }^{2}$ Mohammad Parastesh, ${ }^{3}$ Parvin Dokht Bayat ${ }^{1}$ \\ ${ }^{1}$ Department of Anatomy, School of Medicine; ${ }^{2}$ Department of Molecular Medicine and Biotechnology, Faculty of \\ Medicine; ${ }^{3}$ Department of Sport Physiology, Faculty of Sport Sciences, Arak University, Arak, Iran
}

\begin{abstract}
Adiponectin and its receptors are expressed in the male reproductive system, which play a role in regulating male sex hormones and fertility. Diabetes was induced by Streptozotocin-Nicotinamide (STZ-NA i.p) in rats and after performing the trainings, adiponectin gene expression and its receptors in the testis were evaluated using real time PCR, and blood serum was then used in order to assess FSH, LH and testosterone. The STZ-NA significantly increased the fasting blood glucose, gene expression of adiponectin AdipoR1 in the testicles of diabetic rats. A significant reduction in serum testosterone and LH levels were observed in the diabetic group. Resistance and endurance training decreased blood glucose, adiponectin and AdipoR1 gene, and also increased the serum testosterone and LH levels in diabetic rats. Overall, our data suggest the role played by training in improve expression of adiponectin and
\end{abstract}

Correspondence: Parvin Dokht Bayat, Department of Anatomy, School of MedicineArak University of Medical Sciences Sardasht, BasijSquare, Arak University of Medical Sciences, Postal code: 3848176941, Arak, Iran.

Tel.: +989183613626 .

E-mail: Dr.bayat@arakmu.ac.ir

Key words: Diabetes; adiponectin; Adipor1 and Adipor2; sex hormones; training.

Conflict of interest: The authors declare no conflict of interest.

Acknowledgments: The present research is based on the research project approved by the Deputy Director of Research and Technology at Arak University of Medical Sciences. The code of ethics is also included in the description (IR.Arakmu.rec.1395.322) in the ethics committee of the research projects of Arak University of Medical Sciences. In addition, the authors declare their gratitude to all those who helped us in this way.

Received for publication: 29 July 2020.

Accepted for publication: 13 December 2020.

${ }^{\circ}$ Copyright: the Author(s), 2021

Licensee PAGEPress, Italy

Journal of Biological Research 2021; $94: 9287$

doi:10.4081/jbr.2021.9287

This article is distributed under the terms of the Creative Commons Attribution Noncommercial License (by-nc 4.0) which permits any noncommercial use, distribution, and reproduction in any medium, provided the original author(s) and source are credited.
AdipoR1 gene by increasing the serum testosterone and LH levels in type 2 diabetic rats.

\section{Introduction}

Diabetes is a disorder in the carbohydrates, fats and proteins metabolism that blood glucose increases in conditions of resistance to insulin or insulin deficiency. ${ }^{1}$ Type 2 diabetes or also known as Non-Insulin Dependent Diabetes (NIDDM) with $90 \%$ of cases being the most frequent type of diabetes. ${ }^{2}$ Type 2 diabetes by increasing blood glucose levels can cause physiological and functional disorders in various body tissues, along with behavioral and sexual disorders. ${ }^{3}$ Approximately $90 \%$ of diabetic men suffer from their sexual ability reduction and fertility disability. ${ }^{4}$ Diabetes mellitus caused reduced infertility by altering the cells and the hormones structure involved in the spermatogenesis process. ${ }^{5} \mathrm{~A}$ great deal of research has been accomplished on the association between diabetes and male fertility, which reported lower levels of LH, FSH, testosterone and reducing the sperm parameters and spermatogenesis quality. ${ }^{6}$ Adiponectin is a protein hormone secreted mainly by the white adipose tissue ${ }^{7}$ that plays a significant role in glucose and lipid metabolism. ${ }^{8}$ Adiponectin has 2 receptors: Adiponectin-receptor1 $\left(\right.$ Adipo $\left._{1}\right)$, which is abundantly expressed in skeletal muscle cells, Adiponectin-receptor2 (Adipo $\left.\mathrm{R}_{2}\right)$ that is expressed in the liver cells. ${ }^{9}$ Adiponectin and its receptors are found in organs associated with the male reproductive system like the pituitary, hypothalamus and testicles. Adiponectin is expressed by leydig cells, spermatozoa and epididymis in the testicles. ${ }^{10}$ Few studies have indicated that adiponectin is expressed in the spermatogenesis and sperm maturation at the testis level. Adiponectin reduces the release of gonadotropin releasing hormone $(\mathrm{GnRH})$ from the hypothalamus neurons, and afterward prevents $\mathrm{LH}$ from the pituitary releasing and it has no effect on FSH. On the other hand, this hormone activates its receptors in the testicular tissue, which results in phosphorylation of the active protein kinase AMP (AMPK) and also activating the peroxisome proliferator activated receptor alpha (PPAR- $\alpha$ ), which inhibits testosterone secretion by leydig cells. ${ }^{11}$

Suitable diet and exercise are considered as the diabetes care basis. The effect of exercise on male fertility depends on volume and severity. ${ }^{12}$ Diabetic patients' exercise could reduce blood glucose levels by increasing the protein of the GLUT $_{4}$ vector and the insulin receptor substrate, and also by muscle mass increasing. The effect of exercise on the amount of adiponectin has not yet been fully elucidated because of the lack of consistent results in various studies. ${ }^{13}$ This study purpose was to investigate the resistance and endurance training effect on the adiponectin genes expression and its receptors and sex hormones in type 2 diabetic rats. 


\section{Materials and methods}

\section{Experimental animals and protocols}

Research and animal care were approved by the Ethics Committee of Arak University of Medical Sciences. In vivo experiments were performed on 10 week's old adult male Wister rats with weight between 200-250g (Pasteur, Iran). Animals were housed under the standard conditions $\left(24^{\circ} \mathrm{C}\right.$, cycles of 12 hours light $/ 12$ hours, in darkness) with free access to water and food supplies; 48 animals were divided into following groups by random, before performing the operation procedure ( 8 rats in each group): healthy control, diabetic control, healthy resistance training, healthy endurance training, diabetic endurance training, diabetic resistance training.

\section{Induction of Diabetic type 2}

Streptozotocin (STZ) (Sigma Chemical Co) was dissolved in 0.1 $\mathrm{M}$ citrate buffer ( $\mathrm{pH} 4.5$ ) and Nicotinamide (Sigma Chemical Co) was dissolved in saline (0.9\%). Type 2 diabetes mellitus was induced in overnight fasted rats by injecting a single intraperitoneal (i.p.) of $120 \mathrm{mg} / \mathrm{kg}$ Nicotinamide, by passing $15 \mathrm{~min}$ from the i.p. administration of $65 \mathrm{mg} / \mathrm{kg}$ of STZ. Hyperglycemia was confirmed by the elevated glucose levels in blood, determined at 72 hours. The animals with a blood glucose concentration above $250 \mathrm{mg} / \mathrm{dL}$ were used for this study. Furthermore, the healthy control rats were intraperitoneally injected with saline $(0.9 \%)$ at a dose of $1 \mathrm{cc}$, in order to be at the condition as same as diabetic groups. ${ }^{14}$

\section{Practice protocol}

The exercise program included two types during10 week of endurance training and resistance training.

\section{Endurance training}

Diabetic and healthy with endurance training: The endurance training was accomplished on a rodent motor-driven treadmill at a $0^{\circ}$ slope. The rats exercised for 5 day/week for duration of 10 weeks. Training blocks contained 3 phases of familiarization, overload, and finally preservation and stabilization of exercise intensity. Accordingly, in the familiarization phase (first week), the rats ran at treadmill with the speed of $8 \mathrm{~m} / \mathrm{min}$ for $10-15$ minutes every day. After that, During overload phase (second to fourth weeks), the rats initially ran at treadmill speed of $27 \mathrm{~m} / \mathrm{min}$ for 20 minutes, and then the time of exercise increased ( 2 minutes in each session) gradually during 3 weeks until reaching to 60 minutes. Finally, in the preservation and stabilization stage of exercise intensity, the rats did the aerobic exercise for duration of 7 weeks with a speed of $27 \mathrm{~m} / \mathrm{min}$ for 60 minutes. Each exercise session began with 5 minutes warming up $(16 \mathrm{~m} / \mathrm{min})$, and 5 minutes was allocated to cooling down $(16 \mathrm{~m} / \mathrm{min}$ and gradual reduction of intensity to the least amount). ${ }^{15}$

\section{Resistance training}

Diabetic and control with resistance training: at the first stage, the rats were familiarized with vertical ladder (build by researcher) and learnt how to climb stairs. At this stage, animals were trained for 8 weeks, 5 sessions in each week and 3 sets per session, each one of them with 4 times climbing a special ladder up to one-meter-high and comprising 26 steps. Also, 1 minute rest was considered for animals between each set. At the second stage: from the first week beginning, $30 \%$ of the weight of the animal was connected to the tail of the animal each week, until reaching $200 \%$ of the weight of the animal in the last week. ${ }^{16,17}$

\section{Measurement of sex hormones}

By passing 24 hours from the last exercise session, all of the rats were killed by intraperitoneally injecting a combination of ketamine $(70 \mathrm{mg} / \mathrm{kg}$ ) and xylazine $(4 \mathrm{mg} / \mathrm{kg})$. Their blood samples were collected by cardiac puncture $(5 \mathrm{cc})$ and centrifuged at $3500 \mathrm{rpm}$ for 10 min, and the serum samples were stored for future analysis at $-70^{\circ} \mathrm{C}$. Testosterone, $\mathrm{LH}$ and FSH serum levels were assayed using a variety of kits with respect to their manufacturer's instructions. Testosterone (Rat ELISA Kit, Eastbiopharm Cat. No Ck-E90243, China, sensitivity: $0.25 \mathrm{nmol} / \mathrm{L}$, Assay range: $0.5-100 \mathrm{nmol} / \mathrm{L}$ ), LH (Rat ELISA Kit, Eastbiopharm Cat. No Ck-E90904, China, sensitivity: 0.11mIU/L, Assay range: 0.2-60mIU/L) and FSH (Rat ELISA Kit, Eastbiopharm Cat. NoCk-E30597, China, sensitivity: 0.12mIU/L, Assay range: $0.2-60 \mathrm{mIU} / \mathrm{L})$.

\section{Real time polymerase chain reaction}

After sampling, total RNA was isolated by the use of RNXPlus reagent (Yektatajhiz, Iran) in terms of the manufacturer's instructions. The concentration $\square$ of RNA was measured spectrophotometrically at $260 \mathrm{~nm}$ wavelength using spectrophotometer (Eppendorf, Germany). After that, $3 \mu \mathrm{gr}$ of total RNA was reverse Tran scripted into complementary DNA (cDNA) using Revert Aid ${ }^{\text {TM }}$ First Strand cDNA Synthesis Kit (Parstous, Iran), regarding manufacturer's protocols. Relative gene expression was measured by quantitative real time PCR by the use of SYBR green DNA PCR Master Mix (Sina Colon, Iran) and Life Cycler 96 system (Roche Diagnostics Gmblt, Germany). The PCR was performed in total volume of $20 \mu \mathrm{L}$ containing $1 \mu \mathrm{L}$ of cDNA template, $0.2 \mu \mathrm{L}$ of each of the primers, $10 \mu \mathrm{L}$ of SYBR green Master Mix and $7 \mu \mathrm{L}$ of nuclease-free distilled water. Moreover, each sample was loaded in duplicate.

The sequences of primers that was used for amplifications are summarized in Table 1. The PCR conditions were $95^{\circ} \mathrm{C}$ for $10 \mathrm{~min}$ followed by 45 cycles at $95^{\circ} \mathrm{C}$ for $15 \mathrm{sec}, 60^{\circ} \mathrm{C}$ for $25 \mathrm{sec}$ and $72^{\circ} \mathrm{C}$ for $30 \mathrm{sec}$, respectively. Furthermore, melt curve analysis was performed after each run in order to check the non-specific PCR products and primer dimers presence. The relative mRNA expression was determined using the $2^{-\Delta \Delta C T}$ method and $\beta$-actin as an internal control as shown in Table 1.

\section{Statistical analysis}

A Shapiro-Wilk test was applied for determining the normality of measures distribution, which was found to be normally distributed. After that, a Leven test indicated that the variances were homogeneous. A one-way Analysis Of Variance (ANOVA) was performed for determining the presence of differences amongst groups. Significant differences were quantified by the use of a post hoc test (Tukey). Moreover, data were expressed as Means \pm SEM and significance was set at the alpha level $P \leq 0.05$.

\section{Results}

\section{Blood glucose}

The results showed that in diabetic and diabetic rats with endurance training and resistance training, pre-exercise fasting blood glucose levels are significantly increased in comparison with the healthy control group $(\mathrm{p}=0.01)$ (Table 2$)$. Endurance and resistance training in healthy and diabetic groups have significantly reduced post-exercise blood glucose levels in comparison with the diabetic control group (Table 2). This study indicates that 10 -week 
endurance and resistance training is an effective way for reducing the level of blood glucose in diabetic rats.

\section{The expression of adiponectin and Adipo $_{1}$ and Adipo $_{2}$ gene}

Data Analysis showed that in the rats of different groups, the relative expression of adiponectin gene was significantly increased in healthy control group compared to the diabetic control group $(\mathrm{p}=0.02$, Figure 1$)$.

The relative expression of Adipo $_{1}$ gene in the diabetic control group was significantly increased compared to the healthy control group ( $\mathrm{p}=0.03$ ), while the diabetic endurance with training group showed a significant reduction compared to the healthy control group and the other group ( $\mathrm{p}=0.02$, Figure 2$)$. There was no significant difference in the relative expression of Adipo $\mathrm{R}_{1}$ gene in comparison with healthy control group (Figure 2). Therefore, it appears that both methods of training can reduce the relative expression of adiponectin and AdipoR1 gene in diabetic rats with endurance and resistance training in comparison with diabetic control group.

\section{No change in the expression of the $\operatorname{AdipoR}_{2}$ gene in Diabetic groups}

Diabetes did not alter the expression of Adipo $\mathrm{R}_{2}$ gene in testicular tissue compared to the healthy group. Data analysis showed that in comparison with different groups of rats, the relative expression of Adipo $R_{2}$ gene expression was significantly increased in healthy endurance training and healthy resistance training groups ( $\mathrm{p}=0.03$, Figure 3 ). Endurance diabetic training group and diabetic resistance training in comparison with the healthy control group showed a significant decrease $(\mathrm{p}=0.02)$. The relative expression of Adipo $_{2}$ gene expression in diabetic rats of control group showed a significant reduction compared to diabetic rats of the resistance training group. The relative expression of $\mathrm{AdipoR}_{2}$ gene expression in comparison between diabetic rats with resistance training, the diabetic control group showed a significant reduction. However, in resistance training group the relative expression of this gene increased compared to the control group (Figure 3).

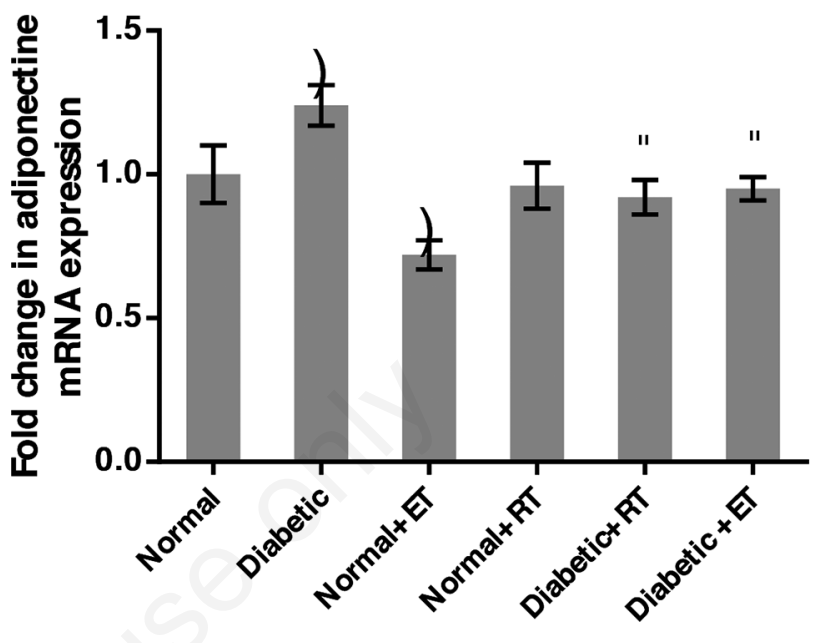

Figure 1. One-way ANOVA was used to compare the relative expression of adiponectin gene in the study groups. The sign $\left(^{*}\right)$ indicates a significant difference compared to the normal group and the sign (\#) that shows a significant difference compared to the diabetic group. Data was reported as Mean \pm SEM $(\mathrm{p}<0.05)$. Abbreviations: ET: Endurance training; RT: Resistance training.

Table 1. Primer sets used for amplification.

\begin{tabular}{|c|c|c|}
\hline Target genes & Primers sequences ( $5^{\prime}$ to $3^{\prime}$ ) & TM \\
\hline Adiponectin- FW & 5'AGGTTGGATGGCAGGCATC -3' & 58.83 \\
\hline Adiponectin-RV & 5'-GGCTCTCCTTTCCTGCCAG -3' & 60.98 \\
\hline AdipoR $R_{1}-F W$ & 5'-CTTCTACTGCTCCCCACAGC- 3' & 61.40 \\
\hline Adipo $R_{1}-R V$ & 5'-TCCCAGGAACACTCCTGCTC -3' & 61.40 \\
\hline Adipo $R_{2}-F W$ & 5'-CCACACAACACAAGAATCCG -3' & 57.30 \\
\hline Adipo $R_{2}-R V$ & 5'-CССTTCTTCTTGGGAGAATGG -3' & 59.82 \\
\hline$\beta$-actin-FW & 5'TCACCCACACTGTGCCCCATCTACGA -3' & 67.95 \\
\hline$\beta$-actin-RV & 5'CAGCGGAACCGCTCATTGCCAATGG -3' & 67.90 \\
\hline
\end{tabular}

Table 2. Body and left testis weight (Means \pm SD).

\begin{tabular}{lccccc} 
Groups & \multicolumn{2}{c}{ Body Weight $(\mathrm{g})$} & Fasting blood glucose (mg/dL) & Testis Weight left $(\mathrm{g})$ \\
\hline Normal & Pre test & Post test & Pre test & Post test \\
Diabetic & $242.9 \pm 21$ & $280.3 \pm 35$ & $88.4 \pm 10$ & $100.2 \pm 12$ & $1.58 \pm 0.19$ \\
\hline Normal+ET & $236.6 \pm 36$ & $253.2 \pm 46^{\mathrm{a}}$ & $299.3 \pm 46^{\mathrm{a}}$ & $366.4 \pm 102^{\mathrm{a}}$ & $1.31 \pm 0.25^{\mathrm{a}}$ \\
Normal+RT & $248.7 \pm 19$ & $250.1 \pm 25^{\mathrm{a}}$ & $85.6 \pm 8^{\mathrm{b}}$ & $76.1 \pm 4^{\mathrm{b}}$ & $1.57 \pm 0.17_{\mathrm{b}}$ \\
\hline Diabetic+ET & $239.7 \pm 16$ & $245.1 \pm 21^{\mathrm{abc}}$ & $85.6 \pm 8^{\mathrm{b}}$ & $76.1 \pm 4^{\mathrm{b}}$ & $1.58 \pm 0.14_{\mathrm{b}}$ \\
Diabetic+RT & $238.7 \pm 20$ & $227.4 \pm 38^{\mathrm{abcd}}$ & $354.2 \pm 86^{\text {acd }}$ & $188.8 \pm 115^{\mathrm{abc}}$ & $1.40 \pm 0.32^{\mathrm{abcd}}$ \\
\hline
\end{tabular}

a) The significant difference with healthy control group ( $<<0.05)$; b) The significant difference with diabetic control group $(p<0.05)$; c) The significant difference with healthy aerobic training group ( $<0.05)$; d) The significant difference with healthy resistance training group ( $<<0.05)$; e) The significant difference with aerobicdiabetictraining group ( $<<0.05)$. Abbreviations: ET: Endurance training; RT: Resistance training. 


\section{The level of sex hormonal}

The results of the study showed that the means of serum testosterone and LH concentrations significantly decreased in diabetic control group compared to healthy control group $(\mathrm{p}=0.01$ and $\mathrm{p}=0.01$ ). The data also revealed that the means of serum testosterone and LH concentrations of diabetic endurance training group were significantly greater than those of diabetic control group were ( $p=0.01$ and $p=0.02$ ). In the other words, it was thought that endurance training has the ability of compensating the destructive effects of diabetes on sperm parameters through increasing the levels of testosterone and LH serum (Table 3).

\section{Discussion}

Diabetes with in the amount of hormones involved in the process of spermatogenesis and changing the structural of the cellular organs, disrupting the process of spermatogenesis and ultimately decreasing fertility. ${ }^{18}$ Many studies have showed that diabetes result in a reduction in $\mathrm{GnRH}, \mathrm{LH}, \mathrm{FSH}$, and throughout the effect on hypothalamic-pituitary-gonadal axis affects fertility. ${ }^{13}$
Our results indicated that the levels of $\mathrm{LH}$ and testosterone in the serum of diabetic rats decreased. The levels of FSH hormone also decreased in diabetes, however this reduction was not significant.

The adiponectin system (Adiponectin, AdipoR $\mathrm{R}_{1}$ and Adipo $_{2}$ ) was expressed in organs associated with the male reproductive system (hypothalamus, pituitary and testis) in rat and human. ${ }^{11}$ Unlike other adipocytokines, Plasma adiponectin levels concentration in type 2 diabetes decreased. It makes a negative correlation between the concentration of adiponectin with insulin resistance and blood glucose concentration. ${ }^{19}$ Also, Adipo $R_{1}$ and Adipo $R_{2}$ decrease in insulin resistance were associated with obesity and diabetes. ${ }^{20}$ The level of testicular adiponectin in mRNA differed from that of circulating Blood level. ${ }^{21}$ Data analysis also showed that the expression of the adiponectin and AdipoR1 gene in the testicular tissue increased, despite a reduction in their serum level in diabetes. Significant differences in AdipoR $_{2}$ gene is not clear.

As the studies indicate, adiponectin plays important roles in glucose homeostasis and lipid metabolism. ${ }^{22}$ The activation of receptors by adiponectin results in the activation of signaling intermediates and pathways such as peroxisome Proliferator-Activated Receptor alpha (PPAR- $\alpha$ ), AMP-Activated Protein Kinase (AMPK) and Mitogen-Activated Protein Kinase (MAPK). Searching for the bind-

Table 3. The level of follicle stimulating hormone (FSH), $\mathrm{mIU} / \mathrm{mL}$; luteinizing hormone (LH), $\mathrm{mIU} / \mathrm{mL}$; testosterone, $\mathrm{nmol} / \mathrm{L}$; in different groups of rats.

\begin{tabular}{lccc} 
Group & LH $(\mathrm{m} / \mathrm{U} / \mathrm{mL})(\mathrm{n}=6)$ & FSH $(\mathrm{m} / \mathrm{U} / \mathrm{mL})(\mathrm{n}=6)$ & Testosterone $(\mathrm{nmol} / \mathrm{L})(\mathrm{n}=6)$ \\
Normal & $5.01 \pm 0.63$ & $3.77 \pm 0.37$ & $6.28 \pm 0.79$ \\
Diabetic & $3.10 \pm 0.38^{\mathrm{a}}$ & $2.70 \pm 0.47$ & $4.55 \pm 0.54^{\mathrm{a}}$ \\
\hline Normal+TA & $4.31 \pm 0.87$ & $4.22 \pm 0.52^{\mathrm{b}}$ & $6.583 \pm 0.59^{\mathrm{b}}$ \\
Normal+TR & $4.12 \pm 0.45$ & $4.13 \pm 0.62^{\mathrm{b}}$ & $6.56 \pm 1.25^{\mathrm{b}}$ \\
\hline Diabetic+TA & $9.13 \pm 1.14^{\mathrm{ab}}$ & $4.12 \pm 0.66^{\mathrm{b}}$ & $8.68 \pm 0.89^{\mathrm{ab}}$ \\
Diabetic+TR & $8.60 \pm 1.13^{\mathrm{ab}}$ & $4.14 \pm 0.24^{\mathrm{b}}$ & $8.58 \pm 0.89^{\mathrm{ab}}$ \\
\hline
\end{tabular}

a) The significant difference with healthy control group $(\mathrm{P}<.05)$; b) The significant difference with diabetic control group $(\mathrm{P}<0.05)$. Abbreviations: TA: Endurance training; TR: Resistance training.

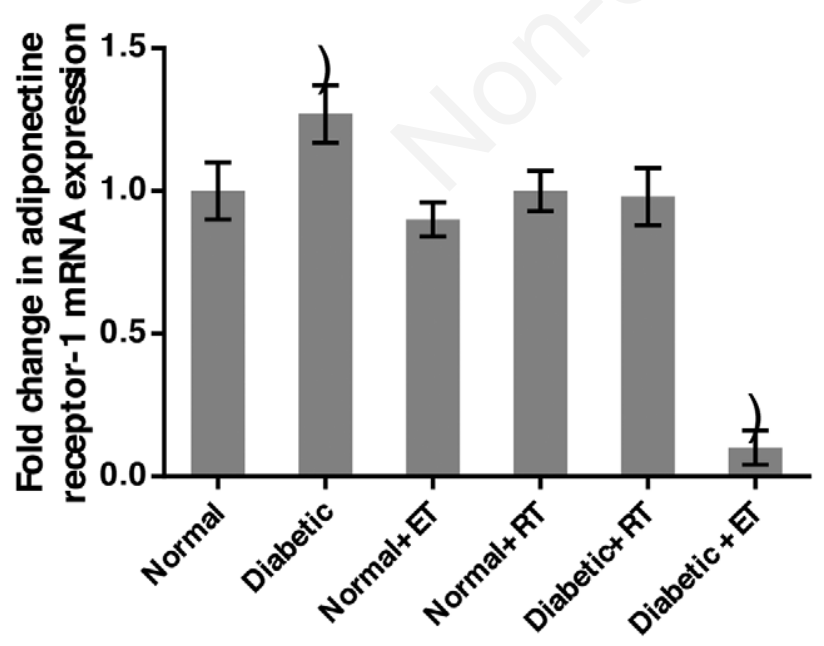

Figure 2. One way ANOVA analysis was used to compare the relative expression of AdipoR1 gene in the study groups. Sign $\left({ }^{*}\right)$ showed a significant difference compared to normal group. And the sign (\#) indicates a significant difference compared to the diabetic group. Data was reported as Mean \pm SEM $(p<0.05)$. Abbreviations: ET: Endurance training; RT: Resistance training.

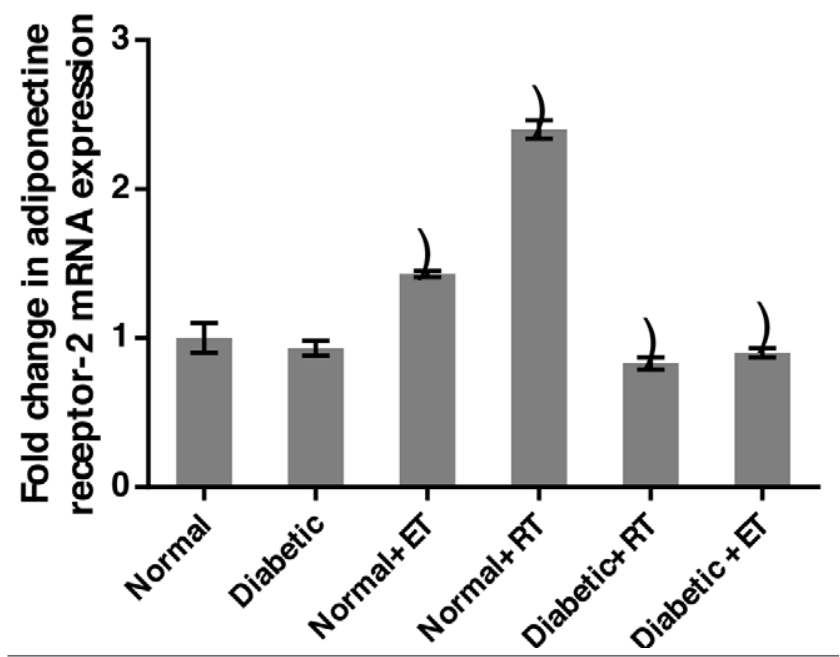

Figure 3. One way ANOVA analysis was used to compare the relative expression of AdipoR2 gene in the study groups. Sign $\left(^{*}\right)$ showed a significant difference compared to normal group. And the sign (\#) indicates a significant difference compared to the diabetic group. Data was reported as Mean \pm SEM $(\mathrm{p} \bigotimes<0.05)$. Abbreviations: ET: Endurance training; RT: Resistance training. 
ing of adiponectin to its receptor in skeletal muscles, the enzyme AMPK, has been phosphorylated and activated. After that, AMPK reduces the enzymes involved in the gluconeogenesis preventing from the liver glucose production. Indeed, adiponectin, by its insulin-like effect, boosts glucose uptake and oxidation of fatty acids, resulting in a reduction in triglyceride accumulation in the liver and adipose tissue, that preventing from the spread of insulin resistance and also metabolic abnormalities improving. ${ }^{10}$

The hypothalamic-pituitary-gonadal axis is central for the mammalian reproductive system. Adiponectin releases Gonadotropin-Releasing Hormones (GnRH) from hypothalamic neurons, and subsequently prevents the LH releasing from the pituitary and testosterone at the testicular level, while its effect is not on FSH anymore. In the testis, AMPK, MAPK, and PPAR- $\alpha$ signaling pathway have been showed to be functional and involved in the steroid genesis regulation. Adiponectin activates the receptors in the testicular tissue, which results in AMPK phosphorylation and activation of PPAR- $\alpha$, which inhibits testosterone secretion by leydig cells. ${ }^{11}$

It can be claimed that adiponectin plays an inhibitory role in the reproductive system. Findings also suggest that testicular adiponectin may act as a paracrine/autocrine factor that could regulate various functions of testicular cells. The results of our research showed that the expression rate of adiponectin and its receptor gene has increased blood glucose levels in testicular tissue. That is caused by the inhibitory role of adiponectin on the production of sex hormones of testosterone and LH. It has declined and finally reduced the spermatogenesis quality.

Caminos et al. (2008) said that the expression of the adiponectin gene, Adipo $R_{1}$ and $\mathrm{Adipo}_{2}$ from the cells of the leydig was accomplished and adiponectin significantly inhibited the secretion of the gonadotropin-based baseline levels of testosterone secretion in the testes. ${ }^{9}$ Ocon-Grove et al. (2008) reported amounts the AdipoR $_{1}$ and Adipo $\mathrm{R}_{2}$ mRNA in the testicles of adult chicks were much greater than immature sexually birds. ${ }^{23}$ Although investigations indicated that the results vary in different animal species and most of these studies are conducted on non-diabetic animals, so the type of study may also be different.

Recent studies have demonstrated that glycemic control may play a key role in reducing the diabetes mellitus effects on infertility. ${ }^{24}$ Exercise (endurance and resistance training) have the capability of reducing blood glucose, improve these fertility. ${ }^{25}$ Exercise in people with diabetes can lower the blood glucose levels and circulating adiponectin by increasing the protein of the glucose transport type4 $\left(\mathrm{GLUT}_{4}\right)$ vector following AMPK activation and the insulin receptor substrate along with increasing muscle mass. ${ }^{26} \mathrm{On}$ the other hand, exercise can improve the endocrine glands performance, which also showed that the results of endurance and resistance training of testosterone and $\mathrm{LH}$ in diabetic rats increased, which could compensate the destructive effects of diabetes. ${ }^{18}$ The present study indicates that 10 -week endurance and resistance training is an effective way could reduce blood glucose and increase sex hormones in diabetic rats.

Many studies have reported a lack of change, increase, or reduction of adiponectin after different treatment protocols. ${ }^{27}$ Garekani et al. (2011) investigated the effect of volume and intensity of exercise on the concentration of plasma adiponectin, liver, muscle and adipose tissue in rats. The results of this study were suggest that the mechanism of adiponectin expression in different tissues is not similar. They also reported that after training (in high and medium volume exercises), adiponectin gene expression was not increased in muscle and liver, but increased in adipose tissue. ${ }^{28}$

Most studies have indicated that both endurance and resistance training can increase the total testosterone level, free testosterone and LH. Tremblay et al. (2005) reported that 40 and 80 minutes of endurance activity would increase the serum levels of free testosterone, total testosterone, and LH. ${ }^{29}$ Kraemer and Ratamess (2005) also examined the responsiveness and hormonal function of the men's activity and resistance training program, and found that resistance exercises result in a significant increasing in serum testosterone level. ${ }^{30}$ Perhaps one of the possible mechanisms is that by increasing the serum levels of testosterone, the expression of the adiponectin gene in the testicle decreases. Hope to be considered in future studies.

Considering the limitations of these studies on the mechanism and the function of the testis in diabetic patients, this type of study can provide a pathway for further investigation and recognition of the exercise effect on the mechanism of testicular activity in diabetic rats, and its effect on the infertility improvement in these rats.

\section{Conclusions}

The induction of diabetes by reducing sex hormones can interfere with reducing the relative expression of adiponectin and AdipoR $_{1}$ gene. On the other hand, it appears that endurance and resistance training could be effective in increasing the levels of $\mathrm{LH}$ and testosterone in the testes by reducing blood glucose, the relative expression of adiponectin gene and its receptors, which can be considered as a strategy for preventing from diabetes mellitus in the rat. Therefore, adiponectin plays an important role in secret sex hormones that can have an effect on fertility in trained diabetic rats.

\section{References}

1. Vaziri P, Vahedi M, Abdollahzadeh S, et al. Evaluation of salivary albumin in diabetic patients. Iranian $\mathrm{J}$ Public Health 2009;38:54-9.

2. Boyle JP, Honeycutt AA, Narayan KV, et al. Projection of diabetes burden through 2050: impact of changing demography and disease prevalence in the US. Diabetes Care 2001;24: 1936-40.

3. Arulrayan N, Rangasamy S, James E, Pitchai D. A database for medicinal plants used in the treatment of diabetes and its secondary complications. Bioinformation 2007;2:22-3.

4. Ramalho-Santos J, Amaral S, Oliveira PJ. Diabetes and the impairment of reproductive function: possible role of mitochondria and reactive oxygen species. Current Diabetes Rev 2008;4:46-54.

5. Roessner C, Paasch U, Kratzsch J, et al. Sperm apoptosis signalling in diabetic men. Reprod Biomed Online 2012;25:292-9.

6. Chandrashekar V, Bartke A. The impact of altered insulin-like growth factor-I secretion on the neuroendocrine and testicular functions. Minerva Ginecol 2005;57:87-97.

7. Yang WS, Lee WJ, Funahashi T, et al. Plasma adiponectin levels in overweight and obese Asians. Obesity Res 2002;10: 1104-10

8. Karbowska J, Kochan Z. Role of adiponectin in the regulation of carbohydrate and lipid metabolism. J Physiol Pharmacol 2006;57:103.

9. Caminos J, Nogueiras R, Gaytán F, et al. Novel expression and direct effects of adiponectin in the rat testis. Endocrinology 2008;149:3390-402. 
10. Yang B, Chen L, Qian Y, et al. Changes of skeletal muscle adiponectin content in diet-induced insulin resistant rats. Biochem Biophys Res Comm 2006;341:209-17.

11. Martin LJ. Implications of adiponectin in linking metabolism to testicular function. Endocrine 2014;46:16-28.

12. Boudou P, Sobngwi E, Mauvais-Jarvis F, et al. Absence of exercise-induced variations in adiponectin levels despite decreased abdominal adiposity and improved insulin sensitivity in type 2 diabetic men. Eur J Endocrinol 2003;149:421-4.

13. Simpson KA, Singh MAF. Effects of exercise on adiponectin: a systematic review. Obesity 2008;16:241-56.

14. Satheesh MA, Pari L. Effect of pterostilbene on lipids and lipid profiles in streptozotocin-nicotinamide induced type 2 diabetes mellitus. J Applied Biomed 2008;6:31-7.

15. Parastesh M, Heidarianpour A. Effects of endurance training on the serum level of sex hormones and sperm parameters after diabetic induction by streptozotocin-nicotinamide. J Shahrekord Uuniversity Med Sci 2017;19.

16. Parastesh M, Saremi A, Ahmadi A, Kaviani M. The effect of aerobic training on serum levels of adiponectin, hypothalamicpituitary-gonadal axis and sperm quality in diabetic rats. Urology J 2019;16:592-7.

17. Parastesh M, Heidarianpour A, Bayat M, Saremi A. Effects of Resistance Training on Serum Level of Reproductive Hormones and Sperm Parameters in Type 2 Diabetes Rats. J Arak University Med Sci 2016;19:26-36.

18. Du Plessis SS, Kashou A, Vaamonde D, Agarwal A. Is there a link between exercise and male factor infertility. Open Reprod Sci J 2011;3:105-13.

19. Cnop M, Havel P, Utzschneider K, et al. Relationship of adiponectin to body fat distribution, insulin sensitivity and plasma lipoproteins: evidence for independent roles of age and sex. Diabetologia 2003;46:459-69.

20. Broedl UC, Lehrke M, Fleischer-Brielmaier E, et al. Genetic variants of adiponectin receptor 2 are associated with increased adiponectin levels and decreased triglyceride/VLDL levels in patients with metabolic syndrome. Cardiovascular Diabetol 2006;5:11.

21. Körner A, Kratzsch J, Gausche R, et al. New predictors of the metabolic syndrome in children-role of adipocytokines. Pediatric Research 2007;61:640.

22. Kadivar A, Khoei HH, Hassanpour H, et al. Correlation of adiponectin mRNA abundance and its receptors with quantitative parameters of sperm motility in rams. International J Fertil Steril 2016;10:127.

23. Ocon-Grove OM, Krzysik-Walker SM, Maddineni SR, Hendricks GL, Ramachandran R. Adiponectin and its receptors are expressed in the chicken testis: influence of sexual maturation on testicular ADIPOR1 and ADIPOR2 mRNA abundance. Reproduction 2008;136:627-38.

24. Amaral S, Moreno AJ, Santos MS, Seiça R, Ramalho-Santos J. Effects of hyperglycemia on sperm and testicular cells of GotoKakizaki and streptozotocin-treated rat models for diabetes. Theriogenology 2006;66:2056-67.

25. Alves M, Martins A, Rato L, Moreira P, Socorro S, Oliveira P. Molecular mechanisms beyond glucose transport in diabetesrelated male infertility. Biochim Biophys Acta 2013;1832:626-35.

26. Pitteloud N, Hardin M, Dwyer AA, et al. Increasing insulin resistance is associated with a decrease in Leydig cell testosterone secretion in men. J Clini Endocrinol Metab 2005;90:2636-41.

27. Manders R, Van JD. Low-intensity exercise reduces the prevalence of hyperglycemia in type 2 diabetes. Med Sci Sports Exerc 2010;42:219-25.

28. Garekani ET, Mohebbi H, Kraemer RR, Fathi R. Exercise training intensity/volume affects plasma and tissue adiponectin concentrations in the male rat. Peptides 2011;32:1008-12.

29. Tremblay MS, Copeland JL, Van Helder W. Influence of exercise duration on post-exercise steroid hormone responses in trained males. European J Appl Physiol 2005;94:505-13.

30. Kraemer WJ, Ratamess NA. Hormonal responses and adaptations to resistance exercise and training. Sports Med 2005;35:339-61. 